\title{
Mathematics and Home Schooling
}

\author{
Kathleen Ambruso Acker, Mary W. Gray, Behzad Jalali, \\ and Matthew Pascal
}

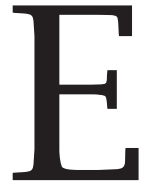

mpowered by the belief that an educated citizenry made for a strong nation, colonial governments as early as 1642 mandated compulsory education for school-age children (Hiatt 1944). Numerate citizens were needed for strong commerce and successful farming, and the governments saw their education as an important objective.

Today parents can choose from public schools, magnet schools, charter schools, private schools, and parochial schools. Despite the varied public and private opportunities available, over 1.5 million students are engaged in home school programs, some of whom will choose to pursue a postsecondary education. Given the increasing attention to national standards for the preparation of students, it is important to understand the climate for, and results of, home schooling insofar as mathematics is concerned.

In our analysis, we address the legal framework surrounding modern home schooling, noting variations in state regulations and curriculum options, with particular attention to mathematics. We then examine how well the structure can be said to prepare students for postsecondary education and whether there are legal remedies if it does not.

Kathleen Ambruso Acker is an independent researcher in mathematics education, who teaches mathematics for American University part time. Her email address is acker@american.edu.

Mary W. Gray is professor of mathematics at American University. Her email address is mgray@american. edu.

Behzad Jalali is director of educational services at American University. His email address is bja 1 a $1 \mathrm{i} @ a m e r i c a n$. edu.

Matthew Pascal is assistant professor of mathematics at Park Point University. His email address is mpasca1@ pointpark.edu.

DOI: http://dx.doi.org/10.1090/noti814

\section{State Mandated Education}

Motivated generally by religiosity, ensuring literate children was a high priority among founding colonists (Gaither 2008). Toward that goal children were taught in the home or in small groups in a religious setting, where in addition to learning how to run a household, farm, or small business, they learned to read, primarily from the Bible. A shift away from home schooling first came in 1635 with the establishment of the first public school in Boston. In 1642 Massachusetts passed a law requiring parents to teach their children how to read and write; the statute gave the state the authority to provide education if the need arose. A second measure, known as the Old Deluder Satan Law or the General School Law of 1647 (Martin 1894), required towns with more than fifty families to hire a teacher and with more than one hundred families to support a grammar school. Massachusetts thus fostered literacy, which in turn meant the population could read and understand the Bible and undertake civic and economic responsibilities or, more colorfully, stay out of the hands of Satan. The costs of running the school and paying the teacher were placed upon the adults responsible for the children to be educated. The passage of this law marks the beginning of compulsory education in the United States. Through the country's history, a basic principle of federalism, namely that the federal government would have limited constitutionally defined powers with other governmental functions reserved to the states, has guided the development of education. In composing the Bill of Rights, the founding fathers notably did not address education; the Tenth Amendment states:

The powers not delegated to the United States by the Constitution, nor prohibited by it to the States, are reserved to the States respectively, or to the people. 
As colonies and territories became states and drew up their own constitutions, each came to include a clause assuming for the state the responsibilities for education. Some of these clauses were limited to providing a basic level of education to assure effective civil and economic participation, while others were broader and more prescriptive as to how this was to be achieved. For example, Vermont in 1827 was the first state to require that educators hold a teaching certificate (Cubberly 1919); other states specified subjects to be taught, often including mathematics.

Although the responsibility for education is clearly assigned to the states, in practice education in the United States has always been a local operation, generally with schools organized into districts by city or county. As the country expanded, so also did enthusiasm for inspiring a sense of civic responsibility through education. Over time home schooling a child was no longer widely prevalent; complementary to the constitutionally mandated state responsibility for education, compulsory attendance laws were instituted. The laws generally authorized private (including religious) school enrollment as meeting these requirements, sometimes prescribing that the education they provide should be equivalent to that in the public schools. Nineteenth- and early twentieth-century litigation upheld the right of the state to carry out its mandate through these laws, including prohibiting home schooling to the extent that the parents who chose to home school were sometimes pursued by the courts on the charge of truancy (Gaither 2008).

In State v. Bailey (1901) the Indiana Supreme Court declared that the natural rights of the parent with regard to the custody and control of his children are subordinate to the power of the state, so that no parent can be said to have the right to deprive his child of the advantages of public education. On the other hand, the lower court in Indiana, in State v. Peterman (1904), found it sufficient to employ a qualified teacher to teach children in the home under the private school provision of the compulsory attendance law, the court declaring that a school is any place where instruction is imparted to the young, a finding echoed by the Illinois Supreme Court half a century later in People v. Levisen (1950).

But the attitude of courts was not always so tolerant. Even conceding the defendant's claim that he was qualified to teach all grades and all subjects taught in the public schools, in Washington v. Counort (1912) the Washington Supreme Court held that teaching his children at home did not qualify as attending a private school and thus home schooling failed to conform to the compulsory attendance law. Directly addressing home schooling again, the Supreme Court of New Hampshire in Hoyt v. Daniels (1919) declared that being schooled at home was not schooling in a private school, the only alternative to public school permitted in the state's school attendance law. Nearly ninety years later, a lower court in California came to the same conclusion (In re Rachel 2008), but in the climate of the political power of the home schooling movement, that decision was overturned in Jonathan v. Superior Court of Los Angeles County (2008), with the court declaring that home schooling was considered to be a private school and could be forbidden only on safety grounds, for example to prevent child abuse (In the matter of William AA, 2005).

An Oregon case is often cited as supporting home schooling, although actually the freedom to run a private school was the issue. The state's compulsory attendance statute required enrollment in the public school system. In fact, although its stated intent included ensuring full opportunity for immigrant children to assimilate as well as mandating integration of children from all economic strata in an effort to achieve equality of educational opportunities, many viewed the law as an anti-Catholic, anti-immigrant measure, no matter how compelling the argument for universal exposure to common values and mingling with diverse populations might be. The U.S. Supreme Court in Pierce v. Society of Sisters (1925) was careful to make clear the state's right and responsibility to regulate education, although not to the extent that the Oregon law contemplated. Although often cited as upholding the freedom of religion clause of the First Amendment, the decision concerned itself more with the business interests of the Society of Sisters school.

A few years earlier, inspired by an excess of nationalistic fervor, Nebraska had passed a law forbidding teaching in a language other than English to students who had not completed the eighth grade. Once again, the Supreme Court (Meyer v. Nebraska 1923) strongly endorsed the right of the state to regulate education as a part of its mandate to provide for it, but found on Fourteenth Amendment equal protection grounds that the Nebraska law was arbitrary and served no rational purpose. Upholding the right of parents to direct the education of their children, at the same time the Court clearly did not contemplate home schooling, asserting, "Education of the young is only possible in schools conducted by especially qualified persons who devote themselves thereto."

Another case often cited for limiting state regulation of school attendance actually also strongly emphasized the state's responsibility to assure the education of children. In balancing the right of parental control with the rights of the state, the U.S. Supreme Court in Wisconsin v. Yoder (1972) allowed an exemption from Wisconsin's compulsory attendance law for the Amish community only because it believed that the very nature of the religion would be undermined with exposure 
of its young people to the worldly culture of education beyond the eighth-grade level. If the state's purpose in education is to prepare children for life, asserted the Court, the limiting nature of education espoused by the Amish was adequate for their separate agrarian way of life. Attempts by other religious groups to claim an "Amish exemption" for their educational practices or lack thereof have not been well received by the courts (Fellowship Baptist Church v. Benton (1987), Johnson v. Charles City Community Schools (1985)).

\section{The Rise of Home Schooling}

We have seen something of the ups and downs of litigation, but it is ironic that the state where public education originated helped set modern legal precedence for home schooling as an education option with the 1978 decision in Perchemlides v. Frizzle (1978). The Perchemlides family had home schooled their older children while living in Boston. After moving to Amherst, they sent their youngest son to the public school system for second grade, where he appeared to regress intellectually and socially. The family opted to continue their son's education at home and filed the required notice with the school district that the family intended to home school. The school district denied the request for four reasons: (a) the parents were not teachers; (b) the curriculum outlined by the family was not linked to the child's current developmental level; (c) the curriculum did not provide for interaction with other groups of children; and d) the child's difficulties were the result of his earlier education, not of the current public school setting. The district superintendent brought a charge of truancy against the parents when they chose to keep their son at home. The court ruled that parents were competent to teach their children and that as long as the curriculum covered those subjects mandated by state law on the mandated time schedule and there was a level of accountability in place, home schooling was a legal option for education in Massachusetts. The case established that home schooling was protected as a state constitutional right subject only to state regulation that must be essential to providing an adequate education. This turnaround in litigation concerning home schooling marked the rise not only of home schooling as an educational philosophy but as a political movement. Although not a decision with precedential value, the cause of the Perchemlides family, particularly their resistance to home inspection visits, was widely embraced by the home schooling community nationally.

Taking a somewhat different approach, the federal court in Jeffery v. O’Donnell (1988) ruled that the Pennsylvania compulsory attendance laws in place were constitutionally vague in the requirement that the curriculum must be "satisfactory" and that a parent must be "properly qualified" and thus constituted a threat to First Amendment freedoms. The aftermath, however, has not been less vague requirements but rather essentially no requirements at all.

\section{Teacher Certification}

As home schooling became more popular, particularly among religious conservatives, courts in different states adopted varying approaches to the practice. Some states focused on teacher certification. In Florida v. Buckner (1985), the Florida Court of Appeal declared that the school attendance statute clearly prohibited an unqualified parent from teaching a child at home under the guise of being a private school. On the other hand, in Delconte v. North Carolina (1985), the North Carolina Supreme Court declared that absent a clear legislative intent, the relevant statute could not be interpreted to prohibit home schooling, but it did not rule whether in fact the state could constitutionally prohibit it were the statute more carefully drafted. The court in Blackwelder v. Safnauer (1988) upheld a statute requiring instruction in home schools to be "substantially equivalent" to that in public schools and to be given by "competent" instructors. Additional rulings upheld a teaching certification requirement for home schooling (Clonlara, Inc. v. Runkel 1989; Hanson v. Cushman 1980; Jernigan v. State 1982; People v. DeJonge 1993). However, it is not clear how similar cases would fare today. In particular, between 1982 and 1992 more than twenty states repealed their teacher certification requirements for home schooling (Dwyer 1994).

All states require public school teachers to hold a teaching certificate, granted after completing a regime of college courses accredited by the state and often including an exam or series of exams covering basic subject matter. In general the curriculum for certification requires that teachers learn about childhood development and psychology and that secondary school teachers be immersed in courses that allow for subject specialization. The No Child Left Behind Act (NCLB) required states to ensure that education should come from a "highly qualified" person, described thusly:

To be deemed highly qualified, teachers must have: 1) a bachelor's degree, 2) full state certification or licensure, and 3) prove that they know each subject they teach (NCLB 2002).

All indications are that the NCLB successor federal legislation will have similar provisions. Private schools are generally exempted from teacher certification requirements, and home schooling is specifically exempted from all provisions of the NCLB. In the states where legal criteria for home school providers are listed, generally the 
qualifications are broadly described and include some or all of the following: parents must be minimally competent, to have taken an education class, to have a GED, to have completed a bachelor's degree. Some states require that homeschoolers successfully complete an interview or periodic meetings with a public school representative, requirements not easily nor uniformly enforced.

In any case, federal legislation is likely to take a narrower view of education than do many homeschoolers. ${ }^{1}$ The NCLB does not mention virtue, morality, or religious conviction as a purpose of education but speaks mainly of quantifiable academic assessment and achievement, exempting home schooling from any accountability for such standards. Should less controversial standards be adopted, home schooling is still likely to be exempt. Establishing the basic right to home school seems beyond effective challenge in the current climate. Uniform enforcement of compulsory education laws is difficult in a home school situation, particularly with public education strapped for funding for the public schools themselves. State regulations or standards to be met are often vague, and overseers generally represent the very school system the homeschoolers seek to escape. Moreover, there are generally no health and safety safeguards, such as compulsory vaccinations, in place. Not only is there a fierce lobby in support of home schooling, but given the inadequacy of many public schools with overcrowding, high failure rates, and confusing standards enforced by tests of questionable value, forcing those currently home schooled into public education might be a cure worse than the disease. However, "disease" does not describe the nature of much home schooling that is an option that is clearly valuable for many children, particularly those with special needs. Nonetheless, there are concerns centered on the acknowledged government obligation to assure education of children for full civic and economic participation.

To further our discussion, we consider the question, Who is a home school student in the United States?, and then we examine two aspects of these concerns: the adequacy of home schooling from a subject matter perspective and the potential for gender discrimination.

\section{Who Chooses to Home School?}

To provide a definition of a home-schooled student, we choose to follow the definition used by The National Center for Education Statistics (NCES), which states:

${ }^{1}$ See, e.g., Friendship Baptist Church, 620 F. Supp at 316: "Tests primarily determine knowledge of content of the subject matter. They do not test other aspects of education necessary to prepare a student for life in today's society."
Students were considered to be home schooled if their parents reported them being schooled at home instead of a public or private school, if their enrollment in public or private schools did not exceed 25 hours a week, and if they were not being home schooled solely because of a temporary illness. (NCES 2001)

The results of the NCES 1999 study found a small percentage (1.7\%) of all school-age children, less than one million, were home schooled, and approximately 20 percent of those students took advantage of services offered at the public school. Services available included curriculum materials, texts, meetings for parents of students, and extracurricular activities (NCES 2003). Follow-up studies conducted by NCES show that by 2003 that number was increasing and by 2007 there were in excess of 1.5 million students home schooled (NCES 2009). Recent reporting from National Home Education Research Institute (NHERI) estimates the number of students in home schooling to be more than two million (www. hs lada. org).

Data show that families who choose home schooling tend to be white, non-Hispanic, twoparent households with only one parent working. Religious beliefs are only one component of why parents report choosing to home school; data in the study also suggest that parents feel they can give their children a better education at home, that the curriculum offered in schools is not challenging their child, and that the school environment is poor (NCES 2001).

Although there are no reliable national statistics, it is the case that many homeschoolers supplement what is taught individually in the home with group study and opportunities for field trips as well as participation in public and private school activities. For the most part the involvement has been in such areas as sports (there are also home school leagues in some sports in some regions) and music. Entitlement to such participation is not clear, although there has been legislation introduced in several states to ensure it under certain conditions.

\section{Curriculum Concerns}

The largest group of homeschoolers consists of Christian evangelicals whose opposition to enrolling their children in public schools is based on two beliefs. One is their desire to avoid the schools' secular nature, in particular their children's potential exposure to and mingling with those whose religious and cultural background differs from their own. They may also object to particular subject matter, such as evolution or the teaching of the validity of and need for respect for different cultures. It even has been said that the teaching of probability should be avoided, since it evolved 
from and is associated with gambling. The highly effective opposition to regulation of home schooling is led by this group through the Home School Legal Defense Association and its lobbying arm, the Congressional Action Program (Stevens 2001).

Other homeschoolers are primarily concerned with the inadequacy of the public schools in meeting the needs of their children, especially those with special needs at either end of the learning spectrum. It is the first group that engenders the concerns cited earlier.

In the 1980s there was a spate of litigation concerning the material covered in public schools. General lack of success was, no doubt, bound to lead to opting out of the system. In Mozert v. Hawkins County Board of Education (1987) plaintiffs objected to requiring the reading of certain textbooks, claiming that it was a burden on the free exercise of religion. Since the First Amendment guarantees this fundamental right, the court chose to adopt an intermediate standard (between rational and strict scrutiny): Do defendants have a compelling interest in requiring all students in grades 1 to 8 to read the basic series of books of a specific publisher? The objections were, not surprisingly, based on the treatment of evolution, but also on what was perceived as endorsement of magic. Although plaintiffs' claim was a lack of balance, testimony at trial also revealed objections to teaching tolerance of religious views other than their own. Finding that public schools serve the purpose of teaching fundamental values "essential to a democratic society," the court concluded that reading the texts was not a burden on freedom of religion and hence that it need not decide whether the compelling interest standard was met, although a concurring opinion asserted that such a state interest would prevail even if there were to be a such a burden. Lacking the ability to tailor the public school curriculum to their views has been a motivating factor in the rise of home schooling. Few states mandate that home schooling cover topics such as tolerance for the religion and culture of others, but many homeschoolers fear any attempt to proscribe curriculum as a threat to their values.

There has been very little research on how well home-schooled students who choose to attend college do or what areas of study they choose. Scores on SATs are generally above the average of those of students as a whole, but the home-schooled students who take such exams are a relatively small, self-selected group.

\section{Home Schooling Requirements by State}

As noted, although until the 1980s most states actually prohibited home schooling, it is now the case that every state permits home schooling subject to varying degrees of regulation as an option under compulsory attendance laws. While ten states do not even require home schooling parents to notify the state of their intent to home school, currently all states have legislated some rules for providing home schooling, with the stringency of the requirements varying widely, as illustrated by the following examples (www.hs7da.org).

Pennsylvania apparently demands much from home school families. In addition to submitting an affidavit of intent to home school, applicants must assure that topics are taught in English, provide immunization records, develop an instructional plan, and maintain a portfolio of accomplishments covering state requirements, including English and mathematics. At the end of each academic year, portfolios are evaluated by experts from the state education authority. However, home school teachers simply must hold the equivalent of a high school diploma. In addition, students in grades 3,5 , and 8 are required to participate in the Pennsylvania System of School Assessment, a statewide requirement for public school students. Enforcement of these requirements appears to be at best sporadic and superficial.

North Carolina requires home-schooled students to maintain immunization records and to keep attendance records. Students are not required to follow a state prescribed curriculum, but they must submit to annual standardized testing in several topics, including English and mathematics, and instructors must hold the equivalent of a high school diploma. For follow-up, the state's rights are limited to simply inspecting test scores.

Nebraska has very little regulation with regard to the policies and procedures home schools must follow. Teachers do not need to meet any qualifications, unless the family hires outside tutors. The state does not require visitation or testing, because it claims it cannot apply the standards for such uniformly across the state. Parents, under oath, swear to provide sequential instruction in several subjects, including language arts and mathematics.

California requires instruction to be in English and attendance records must be kept. Subjects to be studied include English; additional topics may be chosen from the topics covered in the public schools. Mathematics is required only during grades 1 through 6 . No standardized testing is required.

Looking at the states as a whole, we find that currently twenty-eight states and the District of Columbia use "mathematics" for a topic to be learned by those who are home schooled, although content is not specified. North Dakota and Pennsylvania are two states that detail the number of mathematics credits and mention algebra as required study. Seven states note that subjects covered should be comparable to those in the curriculum of the public school system. Three other states only require that students learn arithmetic, 
and no mention is made of higher mathematics. In Vermont the statutory language for required topics notes that students should study the use of numbers. Although the state of Oklahoma strongly recommends the study of mathematics, it does not require it by law. Only three states impose on home-schooled students, by law, high school graduation requirements that include mathematics.

The lack of consistent mathematics requirements and assessment for home-schooled students by some states may seem surprising given the current climate of assessment of educational achievement required by the public school system. NCLB mandated that all students who attend institutions that receive federal subsidies must measure and demonstrate improvement in mathematics and reading ability in the students they educate. In detailing requirements for assessment, NCLB states:

Nothing in this section shall be construed to affect home schools, whether or not a home school is treated as a home school or a private school under State law, nor shall any home schooled student be required to participate in any assessment referenced or authorized under this section (NCLB 2002).

In essence, the home-schooled student does not participate in assessments required by public schools to ensure federal funding. However, twenty-four states require students to be assessed either by standardized exams for math and English or in the form of a personal evaluation or student portfolio review by the school district. How this is enforced is not generally prescribed nor systemically recorded.

Contrasting with the "hands-off" approach to home schooling, at the national level there is a push for the development of a common core standard for language arts and mathematics in the K-12 curriculum. The goal of the core standards is to better prepare students for a college education as well as to compete successfully in a global economy. This state-led effort is not a push for national standards but rather an effort designed to give the fifty states a clear common guideline to discuss what is expected in terms of curriculum and student success in two subjects that are often the focus of assessment. The goal of the standards is to make instruction consistent as well as to provide comparable assessment regardless of geography (www. corestandards.org). States reserve the right to adopt or reject the standards developed.

Undoubtedly, state adoption of the core curriculum standards will result in changes and challenges to educational law and curriculum materials. It is unclear how adopting the standards will affect the home school community; however, the
Home School Legal Defense Association (HSLDA) suggests that adopting a common core is simply a step toward nationalizing education, a move toward which they strongly oppose www.hs7da. org.

\section{Gender Equity}

The major issue we address here is, of course, the adequacy of home schooling with respect to mathematics, especially in light of the limited requirements coupled with apparently nonexistent supervision in most states. There seems little if any prospect of the new impetus for national standards through the core standards or the successor to the NCLB legislation to alter the current situation. Moreover, a concern that has received little attention is the possibility that a substantial portion of the home schooling community may not be providing equal education to girls, in particular in mathematics and science. One commonly used series of texts advises girls who may be good in mathematics not to dream of becoming engineers or scientists but rather to consider how their talent might be used to assist their future husbands (Dwyer 1994).

The traditional American inclination to avoid any federal involvement in education has eroded over the years, tied to federal funding of specific programs but also through enforcement of antidiscrimination laws. In public schools and in private schools that receive federal funds and in some cases even when they do not, constitutional protections (see, e.g., Runyon v. McCrary 1970), federal laws, and some state laws mandate nondiscrimination; however, the major statute, Title IX of the Education Act of 1972, permits exemptions on the basis of religious tenets. In any state action, including education, the Fourteenth Amendment and the due process clause of the U.S. Constitution also provide a basis for assuring equal treatment. Once private actors take on what is a fundamental state function such as education, then they too are bound by constitutional provisions, in particular when the state affirmatively invests parents with the state responsibility for education. Hence one can argue that home schooling parents must provide the same education for their daughters as for their sons. In Norwood v. Harrison (1973), the state's provision of textbooks to schools with racially discriminatory admission policies was found impermissible as inducing, encouraging, or promoting private persons to accomplish what is constitutionally forbidden to the state. However, since the parents are the "state actors", the doctrine affords only intrafamily equity and not interfamily equity (Yuracko 2008).

The concept of homeschoolers as state actors might also be useful if one argues that state constitutional and statutory provisions for education mandate the responsibility of the state to assure at 
least a basic minimal education. Does not the equal protection clause impose a lower limit on state regulation of education (Yuracko 2008, p. 180)? For instance, one could argue that to be a full actor in today's technological world, home-schooled students need computer training and courses in statistics and even calculus (not to mention evolution and other science). The "Amish exemption" from providing an education adequate for the modern world has not in the past been available to those who argue that they do not want their children exposed to concepts that are in conflict with their beliefs, but in the present context of the political strength of the home school movement it is not surprising no one is really challenging the adequacy of home schooling for the state responsibility of full civic and economic participation.

The "state actor" doctrine is not available for every function of government undertaken by private actors-for example, parochial schools may teach religion-but in a responsibility as fundamental as basic education it might be held to apply (as it has to privately operated prisons). And if states can be sanctioned for failing to provide the basic minimum (Abbott v. Burke 1990), why not sanction homeschoolers? Probably insisting on the equivalent of public school education, however defined, is not possible given the finding of San Antonio v. Rodriguez (1973) that while a minimum standard must be met, equity is not required. But can homeschoolers be held to some minimum standard of equitable mathematical training for boys and girls?

The focus on obligations for education of citizens is generally on states. Federal education laws like the NCLB Act and its likely successor have specific statements that they do not authorize any federal control over home schools. However, it has been argued that the "Guarantee Clause of the Fourteenth Amendment authorizes and obligates Congress to ensure a meaningful floor of educational opportunity throughout the nation. The argument focuses on the Amendment's opening words, the guarantee of national citizenship. This guarantee does more than designate a legal status. Together with Section 5 [which assigns to Congress the power to enforce the amendment], it obligates the national government to secure the full membership, effective participation, and equal dignity of all citizens in the national community" (Liu 2006).

But whether the issue is that home schooling provides an adequate mathematical education to meet the responsibility that the state has ceded to homeschoolers or that girls are receiving an inferior education to that of their brothers, an underlying concern is that the children themselves have no legal or practical control over the decision whether they receive the state proffered benefit of a public school education or some other, possibly inferior, form of schooling. The tradition of parental control and, in some cases, free exercise of religion infringes on their children's equal protection rights (Dwyer 1994). In a case involving the right of undocumented children to public education, the Supreme Court found a Texas law excluding them to be a denial of equal protection (Plyler v. Doe 1982). The Court found that the exclusion served no rational state interest, much less a compelling interest. The situation of the children was obvious, and they were represented in the litigation by a guardian, but who might learn of and then bring a legal challenge in the case of inadequate home schooling? Courts are reluctant to confer representation on outside advocates in parent-child conflicts.

Were litigation to occur, religious beliefs of the parents, while sufficient for the Amish when it comes to exemption from high school education, would be unlikely to prevail in the case of basic minimal education. Although an inferior education may not be as life-threatening as is denial of certain medical procedures such as blood transfusions (Jehovah's Witnesses v. King County Hospital 1968), religious objections are unlikely to withstand the scrutiny given to bypassing the state's responsibility, assumed by parents, for basic education as preparation for life.

In the contexts of ensuring the right to vote or to obtain an abortion, courts have held that not only may states not block access but must at a minimum take steps to prevent private interference with these rights (Ex parte Yarbrough, 110 U.S. 651 (1884), Planned Parenthood of Central Missouri v. Danforth 1976). Of course, in the case of home schooling, the interference with the right to a fundamental education comes from parents, and how the state can protect the rights of the home-schooled children is problematic. Permitting third party complaints on behalf of the child or establishing judicial procedures (as in the abortion context) to allow children themselves to challenge the adequacy of their parents' choices is more likely to engender fierce opposition than public support in light of the political power of the home schooling movement. However, it is likely that the majority of responsible and committed homeschoolers would also argue for minimum standards somehow to be ensured, albeit in a nonintrusive manner.

In the case of inferior education for girls, such enunciated fundamentalist beliefs as "sexual equality denies God's word" and failure of a wife to accept a subordinate, obedient role in the home means "the doors are wide open to Satan" may well exclude girls from the level of mathematics known to be a critical filter for many careers and confine them to low-paying, servile occupations if employed outside the home (Yuracko 2008, p. 156). In So Much More: The Remarkable Influence of 
Visionary Daughters on the Kingdom of God, popular in the Christian home schooling community, authors Anne Sofia Botkin and Elizabeth Botkin claim that college is dangerous for young women because it diverts them from their God-ordained role as helpmeets for their fathers and husbands (quoted in Yuracko 2008, p. 157). Stacy McDonald (2005) supplies even more explicit guidance for potentially discriminatory education: A girl's education "should be focused on assisting her future husband as his valuable helpmate, not on becoming her 'own person'." Girls are counseled to "[r]emember that a strong desire to be a doctor or a seeming by-God-given talent in mathematics is not an indication of God's will for you to have a career in medicine or engineering. Sometimes God gives us talents and strengths for the specific purpose of helping our future husbands in their calling." (Quoted in Yuracko 2008, p. 157, note 168.)

When the United States sued Virginia for violating the equal protection clause of the Fourteenth Amendment by denying women admission to the Virginia Military Institute, the Supreme Court, reversing the decision of the federal appeals court, declared "[S]uch sex classifications may not be used as they once were, to create or perpetuate the legal, social, and economic inferiority of women" (United States v. Virginia at 534). The Court went on to say that the state's important interests in education, in order to be constitutional, must undermine sex hierarchy and never reinforce hierarchy or promote sex stereotypes that foster hierarchy. Nonetheless, private single-sex higher education continues without constitutional challenge. However, in the case of basic education for children, the state has taken on the responsibility for its provision but has delegated its authority to parents who home school their children, thus making the parents state actors and subject to the equal protection requirement of the Fourteenth Amendment. Also relevant to the fundamental nature of education and the state's responsibility for it is the contrast between Griffin v. County School Board of Prince Edward County (1964), where the Supreme Court refused to countenance the closing of the public schools to avoid integration, and Palmer v. Thompson (1971), where closing the public swimming pools was permitted.

\section{Conclusion}

McMullen (2002) offers a remedy for the deficiencies such as those identified above: fair-minded, fairly minimal regulation aimed at the minority of bad actors in the home schooling community. She proposes that those who wish to home school be required to file an application with the local school district, to be approved automatically if the name, address, and proof of vaccination are in order (and the parents have not been convicted of child abuse). Age-appropriate competence testing in reading and mathematics would be mandatory in order to maintain home school status, preferably exams like the Iowa Basic Skills Test, which is hard to teach to. There should be independent monitoring of home schooling, since local school personnel could be said to have a conflict of interest. Teacher certification or more detailed regulation would be difficult to institute and not necessarily a solution, leaving only the ultimate remedy of litigation for the very few children who may be being deprived of basic rights.

What can be done to assure adequate training in mathematics and sciences specifically for home-schooled girls? In particular, who has the responsibility and the ability to secure legal protection for them? It can be argued that the state constitutional assumption of education as a state function implies that there is in fact recourse when parents take on the functions of the state.

Will concern for children's rights eventually swing the pendulum of home schooling back to universal substantial regulation if not to outright prohibition? This seems unlikely in the current political climate despite the attention being given to education as a national resource and to the necessity to provide a larger, more diverse, and better-trained STEM workforce if America's global position is not to decline.

Whether home schooling contributes to the goal of better-educated students on the whole or proportionally to the number of students in nationally important STEM disciplines remains to be determined.

\section{References}

AnNe Sofia Botkin and ElizABeth Botkin, So Much More: The Remarkable Influence of Visionary Daughters in the Kingdom of God, The Vision Forum, Inc., San Antonio, Texas, 2005.

Ellwood PATTERSON CUbBerly, Public Education in the United States: A Study and Interpretations of American Educational History, Houghton Mifflin Company, Cambridge, Massachusetts, 1919.

JAMES G. DWYER, Parents' religion and children's welfare: Debunking the doctrine of parents' rights, California Law Review 82 (1994), 1371-1447.

Milton Gaither, Homeschool: An American History, Palgrave Macmillan, New York, 2008.

GooDWIN LIU, Education, equality, and national citizenship, Yale Law Journal 116 (2006), 330-411.

DiANA BuEll HiATt, Parent involvement in American public schools: An historical perspective 1642-1994, The School Community Journal (2) 4 (Fall/Winter 1994), 27-38.

http://www. corestandards.org

http://www.hsTda.org

GEORGE HENRY MARTIN, The Evolution of the Massachusetts Public School System: A Historical Sketch, D. Appleton \& Co., New York, 1894.

STACY MCDONALD, Raising Maidens of Virtue: A Study of Feminine Loveliness for Mothers and Daughters, Books on the Path, Barker, Texas, 2004.

No Child Left Behind, 20 U.S.C. §§6301 et seq. (2002). 
Mitchell L. STEvens, Kingdom of Children: Culture and Controversy in the Homeschooling Movement, Princeton University Press, Princeton, New Jersey, 2001.

U.S. Department of Education, NCES, Home schooling in the United States: 1999, Statistical Analysis Report, July 2001.

U.S. Department of Education, NCES, Home schooling in the United States: 2003, Statistical Analysis Report, July 2006.

U.S. Department of Education, NCES, Home schooling in the United States. Issue Brief, December 2008.

KIMBERLY YURACKO, Education off the grid: Constitutional constraints on homeschooling, California Law Review 96 (2008), 123-180.

\section{Cases Cited}

Abbott v. Burke, 575 A. 2d 359 (NJ 1990).

Blackwelder v. Safnauer, 689 F. Supp. 106 (NDNY 1988). Clonlara, Inc. v. Runkel, 722 F. Supp. 1442 (E.D. Mich. 1989).

Delconte v. North Carolina, 329 S.E.2d 636 (N.C. 1985).

Ex Parte Yarbrough, 110 U.S. 651 (1884).

Fellowship Baptist Church v. Benton, 815 F.2d 485 (8th Cir. 1987)

Florida v. Buckner, 472 So. 2d 1228 (Fla. Court of Appeal 1985).

Griffin v. County School Board of Prince Edward County, 377 US 218 (1964).

Hanson v. Cushman, 490 F. Supp. 109 (WDMich. 1980). Hoyt v. Daniels, 84 N.H. 38 (N.H. 1919) (State v. Hoyt). In re Rachel, 73 Cal. Rptr. 3d 77 (Ca. App. 2d Dist. 2008). In the matter of William A.A., 807 N.Y.S.2d 181 (Supreme Ct. of NY App. Div., 3rd Dept, 2005).

Jeffery v. O’Donnell, 702 F. Supp. 516 (MD Penn 1988). Jehovah's Witnesses in the State of WA v. King County Hospital, 390 U.S. 598 (1968).

Jernigan v. State, 412 So. 2d 1241 (Ala. Crim. App. 1982). Jonathan v. Superior Court of Los Angeles County, 81 Cal. Rptr. 571 (Cal. App. 2d Dist. 2008).

Johnson v. Charles City Community Schools Board of Education, 368 N.W.2d 74 (1985).

Meyer v. Nebraska, 262 U.S. 390 (1923).

Mozert v. Hawkins County Board of Education, 827 F.2d 1058 (6th Cir. 1987).

Norwood v. Harrison, 413 U.S. 1035 (1973).

Palmer v. Thompson 403 US 217 (1971).

People v. DeJonge, 501 NW 2d 127 (Mich. 1993).

People v. Levisen, 90 N.E. 2d 213 (Ill. 1950).

Perchemlides v. Frizzle (Case no.16641, Sup. Ct. of Hampshire County, Mass. 1978).

Pierce v. Society of Sisters, 268 U.S. 510 (1925).

Plyler v. Doe, 458 U.S. 1131 (1982).

Runyon v. McCrary, 427 U.S. 160 (1976).

San Antonio v. Rodriguez, 411 U.S. 980 (1973).

Tate v. Bailey, 61 N.E. 730 (Ind. 1901).

State v. Peterman, 70 N.E. 550 (App. Ct. Ind. 1904).

United States v. Virginia, 518 U.S. 515 (1996).

Washington v. Counort, 124 P. 910 (Wash. 1912).

Wisconsin v. Yoder, 406 U.S. 205 (1972).

\section{Explore Wiley's New and Bestselling Mathematics Titles}

\section{A Must-Have Textbook}

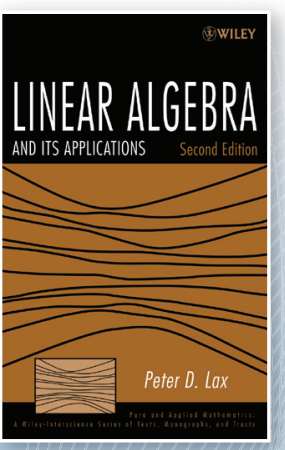

$978-0-471-75156-4$

Hardcover 392 pages

September $2007 \bullet \$ 89.95$

Everything you need to know

about linear algebra is in this book

\section{Featured New Titles}

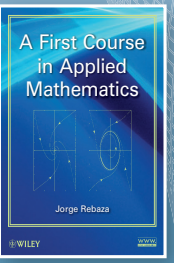

A First Course in Applied Mathematics by Jorge Rebaza

978-1-1182-2962-0 • Hardcover $\bullet 454$ pages

April $2012 \cdot \$ 115.00$

- The book details how applied mathematics involves

predictions, interpretations, analysis, and mathematical

modeling to solve real-world problens.

Mathematical concepts and techniques are reviewed

throughout the book, especially those in linear algebra, matrix

analysis, and differential equations.
The quality, quantity, and varying levels of difficulty of the

exercises provides instructors with more classroom flexibility.

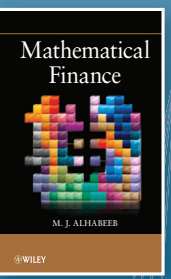

Mathematical Finance

by M. J. Alhabeeb

$978-0-470-64184-2 \cdot$ Hardcover $\bullet 536$ pages

March $2012 \cdot \$ 115.00$

- The chapters explore the mathematical aspects of variou.

financial scenarios.

- Numerous examples and exercises present realistic financial

scenarios that aid readers in applying their newfound

mathematical skills to devise solutions.

- The book is extensively class-tested and an excellent book for

courses in business, economics, and mathematics of finance at

the upper-undergraduate and graduate levels.

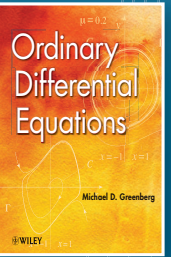

Ordinary Differential Equations

by Michael D. Greenberg

978-1-1182-3002-2 $\cdot$ Hard

- This book features a balance between theory proofs and

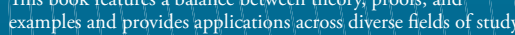

In addition to plentiful exercises and examples throughout the

- In addition to plentiful exercises and examples throughout the
book, each chapter concludes with a summary that outlines key

concepts and techniques.

- The book's design allows readers to interact with the content,

while hints, cautions, and emphasis are uniquely featured in the

margins to further help and engage readers.

Now you can expand your collection of Wiley Math books like never before, by purchasing titles for download on your Kindle, iPad, or other e-Readers.

For additional Mathematics titles, visit www.wiley.com/go/mathematics

(6)WILEY-BLACKWELL 